\title{
Five Years Retrospective Review of Colorectal Cancer Risk Factors in the Black Sea Coast Population
}

\author{
SERGIU IOAN MICU ${ }^{1 *}$, ISMINI ORAIOPOULOU ${ }^{2}$, MADALINA ELENA MANEA ${ }^{3}$, MARILENA MUSAT ${ }^{1}$, \\ ANCA ROGOVEANU ${ }^{1}$, ANDRADA DUMITRU ${ }^{1}$, GABRIEL PREDA ${ }^{1}$, ROXANA POPOIAG ${ }^{1}$ \\ ${ }^{1}$ St Apostle Andrew Emergency Hospital of Constanta, Gastroenterology Department, 145 Tomis Blvd., 900591, \\ Constanta, Romania \\ ${ }^{2}$ University Ovidius of Constanta, Faculty of Medicine, 124 Mamaia Blvd., 900527, Constanta, Romania \\ ${ }^{3}$ St Apostle Andrew Emergency Hospital of Constanta, 2. Diabetes Mellitus and Nutritional Diseases Department, \\ 145 Tomis Blvd., 900591, Constanta, Romania \\ Romania
}

Considering its increasing incidence, complications, comorbidities, mortality and last but not least the tendency to decrease the age of onset, colorectal cancer (CRC) represents one of the significant concerns related to oncology diseases becoming in the last decades a public health problem. Although the etiology is not yet completely known, colorectal cancer is considered a disease with multiple factors, an important place occupying the impact of the environmental factors on the genetically particularly predisposition of patients. In order to reduce the incidence of this disease, screening methods have been developed that are addressed primarily to the population at risk and which have contributed significantly to reducing the occurrence of this condition. The purpose of this paper is to evaluate the presence of specific risk factors for CRC in the Black Sea Coast population for a period of 5 years, and to contribute to the reinforcement of some notions already well known in the specialized literature. By publishing this work, the committee of authors hopes to strengthen the profile of the individual at risk of developing CRC in order to identify better those that are in danger of developing this disease and refer them to screening.

Keywords: Colorectal cancer, risk factors, screening

Colorectal cancer, is the third cause of cancer in men (10\% overall) and the second cause of cancer in women after breast cancer ( $9.4 \%$ of total) and is one of the most commonly occurring malignant tumors in the world, representing $15 \%$ of all malignancies and being responsible for approximately 700,000 deaths annually. [1-6] The epidemiologic data transforms CRC into a public health problem with significant impact on morbidity and mortality of the population worldwide, but also an economical one due to the high costs required for the management of patients with this condition.

Although the causes of this disease are not completely understood, several factors look to influence its occurrence. Risk factors for colorectal cancer include age, family history of colon polyps or CRC, inflammatory bowel disease, and hereditary syndromes, smoking, obesity, diabetes mellitus, sedentary behavior, chronic alcohol consumption, diet deficitary in oligoelements. [7, 8] The discovery of risk factors is an efficient way to selecting persons at high risk for colon cancer, which should be referred for screening.

We aimed to identify and evaluate the presence of risk factors for CRC in the Black Sea Coast population for a period of 5 years and to strengthen the profile of the people at risk of developing CRC in order to identify better those that are in danger of developing this disease and refer them towards a screening method.

\section{Experimental part}

The present study had a retrospective design, between January 2014 and December 2018, and the site was located in Gastroenterology Department of Emergency Hospital of Constanta County. The manner of

*email: micuioansergiu@yahoo.com 
study involved the observation sheets of all patients admitted in the above department, taken randomly, no matter of stage or treatment applied.

From each patient we studied demographic data like gender, age, provenience, and personal data like body mass index, culinary habits, personal medical history, comorbidities, alcohol and smoking habits, personal history of colorectal cancer/polyps and family history of CRC or other cancers.

\section{Results and discussions}

Between January 2014 and December 2019, 8146 patients were hospitalized in the Gastroenterology Department of Emergency Hospital of Constanta County. From the total number of 8146 admissions, 763 cases $(9.36 \%)$ had a diagnosis of colorectal cancer.

The percentage of $9 \%$ of the total admissions may seem small, but it can be explained by the following aspects: for the gastroenterology department, colorectal oncological pathology is strictly a segment of passive detection of cases and most of them are due to the personal addressability of patients $(65 \%$ of patients), a quite small number of patients coming with direct addressability from the family doctor (35\% of patients), which is also a feature of the fact that active screening remains a deficient point of primary health care; the emergence of the private health system reduced the addressability of patients to the state hospital, the relatively small number of patients admitted to the gastroenterology department could also be viewed from this point of view. However, related to the total working days, it can be practically appreciated that once every two days there was a case of colorectal cancer approached, this suggesting that this pathology is not a rare one found in the Black Sea Coast population.

From the total of 763 cases of colorectal cancer diagnosed, 494 were males, and 294 were females, with a sex ratio of $1.4 / 1$. The overall greater incidence of CRC in men corresponds to the data in the literature. [9]It is not fully known why CRC affects men more than women, but this may be explained by the fact that men are more likely to exhibit exogenous risk factors (gender related behavior) such as: great alcohol consumption, smoking, red meat and processed food consumption, predisposition to deposit visceral fat. $[10,11]$

According to the provenience of patients, from the total number of 763 patients diagnosed with CRC, 501 patients $(65.66 \%)$ came from the urban area while 262 patients $(34.33 \%)$ came from the rural area. This feature is also related in literature and can be explained through the following points of view: the people from the urban area are more exposed to risk factors due to their lifestyle than people from rural areas; the population in the urban area has a wider access to medical services and implicitly to modern methods of diagnosis. $[12,13]$

Regarding age distribution, out of a total of 763 patients, most patients diagnosed with CRC were over 50 years old (558 patients), representing 73\%, with an incidence peak between 60-69 years (150 patients).These results are similar to those in the literature, which states that the highest incidence of CRC is found in the population in the second decade of life.

A diet deficient in fibers and rich in proteins/lipid, sugar and thermally processed aliments, is considered a risk factor for CRC. Alcohol intake is also found to be related to CRC occurrence. Opposite, a diet rich in fresh fruits and vegetables, especially without thermal intervention is considered to have a protective role against CRC development. [14-17] In our series of patients, statistics showed a more significant prevalence of the disease in those having a diet rich in proteins, lipids, and sugars (39\%) than in those that were having a diet rich in fresh fruits and vegetables $(\mathrm{p}=0.022$, $\mathrm{ss}, \mathrm{p}=0.012$, ss) (Table 1.)

Table 1

DISTRIBUTION OF PATIENTS WITH COLORECTAL CANCER BY ALIMENTARY HABITS

\begin{tabular}{|c|c|c|}
\hline Alimentary habit & $\begin{array}{c}\text { Total number of patients with } \\
\text { colorectal cancer }\end{array}$ & Percent \\
\hline Diet with an excess of protein/lipid & 222 & $39.44 \%$ \\
\hline High fiber diet & 69 & $9.04 \%$ \\
\hline Mixed diet & 171 & $29.09 \%$ \\
\hline Carbohydrates & 301 & $22.41 \%$ \\
\hline Total & 763 & $100 \%$ \\
\hline
\end{tabular}

Regarding alcohol consumption, daily or occasional consumption was found in most patients diagnosed with CRC ( $\mathrm{p}=0.0018$, ss), (Table 2). 
Table 2

DISTRIBUTION BY ALCOHOL FREQUENCY CONSUMPTION

\begin{tabular}{|c|c|c|}
\hline Alcohol consumption & $\begin{array}{c}\text { Total number of patients with } \\
\text { colorectal cancer }\end{array}$ & Percent \\
\hline Daily & 370 & $48.49 \%$ \\
\hline Occasionally & 349 & $45.74 \%$ \\
\hline Never & 44 & $5.76 \%$ \\
\hline Total & 763 & $100 \%$ \\
\hline
\end{tabular}

Lack of physical activity, obesity and visceral fat is associated with a higher risk of developing CRC. In our study, most patients reported a moderate and low level of physical activity, accounting for almost $83 \%$ of the total patients. [18-21] Regarding fat status, although BMI is not a reliable indicator of fat loading, in our study, most patients diagnosed with CRC were overweight(29\%) and obese(53\%) (Table 3).

Table 3

DISTRIBUTION OF PATIENTS BY BMI

\begin{tabular}{|c|c|c|}
\hline Body mass index & Patients with CRC & Percent \\
\hline Normal weight(BMI<25) & 138 & $29 \%$ \\
\hline Overweight(BMI=26-29) & 222 & $53 \%$ \\
\hline Obesity(BMI>30) & 403 & $\mathbf{1 0 0 \%}$ \\
\hline Total & $\mathbf{7 6 3}$ & \\
\hline
\end{tabular}

Smoking is considered a "universal carcinogen", recent research showing a link between nicotine consumption and CRC development. [22] In our study, the vast majority of patients diagnosed with CRC were smokers $(88 \%)$, and of these $75 \%$ had smoked for over 20 years.

Comorbidities considered risk factors for colorectal cancer development were also encountered in our study. [23, 24] Diabetes mellitus, inflammatory bowel disease (IBD), and personal history of polyps were evaluated as risk factors for our patients. Diabetes mellitus is considered an independent risk factor for colorectal cancer occurrence. [25-27] In our study from the total number of 763 patients diagnosed with CRC, 217 patients $(28.44 \%)$ had a type of glucose metabolism disturbance. According to the type of glucose disturbance, 16 patients had type 1 diabetes, and 123 had type 2 dyabetes, the rest having a genetic predisposition and occasionally increased glucose levels in the serum. [28] Inflammatory bowel diseases are also known to be significant risk factors, especially after 10-15 years of disease progression, the risk being bigger in Ulcerative Colitis than in Crohn's Disease. In our study, almost $8 \%$ of patients (60 patients) had a long history of IBDs. From these, 45 patients $(74 \%)$ had a history of Ulcerative Colitis, and the rest of 13 patients (21\%) had Crohn's Disease with colon involvement (Table 4).

Table 4

IBDS PRESENCE IN THE PATIENT'S MEDICAL HISTORY

\begin{tabular}{|l|l|l|}
\hline Inflammatory bowel diseases & Number & Percent \\
\hline Ulcerative colitis & 45 & $73.77 \%$ \\
\hline Crohn's Disease & 13 & $21.31 \%$ \\
\hline Indeterminate colitis & 2 & $3.27 \%$ \\
\hline Total & $\mathbf{6 0}$ & $\mathbf{1 0 0 \%}$ \\
\hline
\end{tabular}

The sequence adenoma- adenocarcinoma is very well depicted in the CRC pathogeny. In this direction, we followed up the presence of colorectal polyps in the personal history of our studied patients. From the total of 763 patients diagnosed, 228 patients (29.88\%) had previous or concomitant polyps along the colorectal tract. Genetic inheritance plays an important role in the emergence of CRC. [29-34] In our study, of the 763 patients tested, family history of colorectal cancer was present in 401 patients (53\%); of these, 298 individuals $(39.05 \%)$ had first degree relatives, and the rest of them (14\%) had second and third-degree relatives diagnosed with CRC. Family history of other types of cancer than colorectal one was also encountered in our patients. From a total of 763 patients, 188 patients $(24 \%)$ had different types of cancer in family history, especially digestive ones. 


\section{Conclusions}

In the hope of accentuating as much as possible the profile of the individual at risk of developing CRC, our study has presented a series of arguments that do nothing but emphasize a series of notions already well rooted in the literature. We noted a male and urban site predominance, and the peak age was over 60 years. Overweight and obesity, diabetes mellitus, and the lack of physical activity were independent risk factors for $\mathrm{CRC}$ in our study. Diet rich in vegetables and fruits reduces the risk of developing CRC, while a diet rich in fats, lipids, and carbohydrates was more involved as a risk factor for CRC in our series. Moderate and heavy alcohol intake, along with everyday smoking were behavior habits involved in CRC occurrence in our patients. Family history of CRC, other digestive cancers, personal history of CR polyps or cancer were also detected as significant risk factors in our statistic analyze.

\section{References}

1.MEESTER, RGS., MANNALITHARA, A., LANSDORP-VOGELAAR, I., LADABAUM, U., JAMA, 321, 2010, p. 1933.

2.CRONIN, K.A., LAKE, A.J., SCOTT, S., ET al. Annual Report to the Nation on the Status of Cancer, part I: National cancer statistics. Cancer, 124, 2018, p 2785.

3.SUCEVEANU, A.I., SUCEVEANU, A.P., VOINEA, F.L., MAZILU, L., MIXICI, F., ADAM, T. , Journal of Gastrointestinal and Liver Diseases, 18, no. 1, 2009, p. 33-38.

4.KOLLIGS, FT., Visc. Med., 32, 2016, p. 158-164.

5.BOLOCAN, A., PADURARU, D.N., NITIPIR, C., HAINAROSIE, R., SILIU, M.P., DIACONU, C., SUCEVEANU, A.P., STOIAN, A.P., Romanian Biotechnological Letters, 23 no. 6, 2018, p. 14193- 14203.

6.MAZILU, L., CIUFU, N., GALAN, M., SUCEVEANU, A.I., SUCEVEANU, A.P., PAREPA, I.R., TOFOLEAN, D.E., Chirurgia (Bucharest), 107 no. 1,2012 , p. 55-58.

7.SUCEVEANU, A.I., MAZILU, L., NITIPIR, C., STOIAN, A.P., PAREPA, I. , VOINEA, C., SUCEVEANU, A.P., Rev. Chim. (Bucharest), 70 no. 5, 2019, p. 1808-1811.

8.MARLEY, AR., HONGMEI, N., Int. J. Mol. Epidemiol. Genet., 7 no. 3, 2016, p. 105-114.

9.TULIN, A.,SLAVU, I., TULIN, R., et al., Journal of mind and medical sciences, 5 no. 1, 2018, p.101-108.

10.STOIAN, A.P., BALA, C., RUSU, A., SUCEVEANU A.I., DUMITRU, C.B., NITIPIR, C., DITU, G., BICA, C., PADURARU, D.N., SERAFINCEANU, C., Rev. Chim.(Bucharest), 69 no. 4, 2018, p. 854-869

11.PANTEA STOIAN, A., ELIAN, V., NITIPIR, C., et al., Conference: 3rd International Conference on Interdisciplinary Management of Diabetes Mellitus and its Complications,(INTERDIAB)Location: Bucharest, ROMANIA Date: MAR 02-04, 2017 Sponsor(s): Assoc Renal Metab \& Nutrit Studies; AstraZeneca Diabetes; MSD Diabetes; novo nordisk; SANOFI NTERDIAB 2017: DIABETES MELLITUS IN INTERNAL MEDICINE Book Series: International Conference on Interdisciplinary Management of Diabetes Mellitus and its Complications, 2017, p. 232-242.

12.GHEORGHE, A.D., SUCEVEANU, A.I., SUCEVEANU, A.P., TOFOLEAN, D., MAZILU, L., Oncolog-Hematolog.ro, 46 no.1, 2019.

13.GALAN, M., MAZILU, L., SUCEVEANU, A.I., SUCEVEANU, A.P., LOISIOU, T., VOINEA, F.., Ars Medica Tomitana (Constanta), 1 no. 60, 2010, p. 65-72.

14.ORLICH, M.J., SINGH, P.N., SABATE, J., et al., JAMA Intern. Med., 175,2015, p.767.

15.CIOCIRLAN, M.,DRAGHIA, L., MANUC, D., et al. Conference: 3rd International Conference on Interdisciplinary Management of Diabetes Mellitus and its Complications,(INTERDIAB)Location: Bucharest, ROMANIA Date: MAR 02-04, 2017 Sponsor(s): Assoc Renal Metab \& Nutrit Studies; AstraZeneca Diabetes; MSD Diabetes; novo nordisk; SANOFI INTERDIAB 2017: DIABETES MELLITUS IN INTERNAL MEDICINE Book Series: International Conference on Interdisciplinary Management of Diabetes Mellitus and its Complications 2015, p. 132138.

16.CIUHU, A.N., PANTEA-STOIAN, A.M., NITIPIR, C., et al., Conference: 3rd International Conference on Interdisciplinary Management of Diabetes Mellitus and its Complications (INTERDIAB)Location: Bucharest, ROMANIA Date: MAR 02-04, 2017 Sponsor(s): Assoc Renal Metab \& Nutrit Studies; AstraZeneca Diabetes; MSD Diabetes; novo nordisk; SANOFI INTERDIAB 2017: DIABETES MELLITUS IN INTERNAL MEDICINE Book Series: International Conference on Interdisciplinary Management of Diabetes Mellitus and its Complications 2017, p. 139-147.

17.NITIPIR, C.,DIACONU, C.C., ORLOV, C.,et al., Conference: 35th Balkan Medical Week on Healthy Ageing - An Endless Challenge, 2018, p.133-137.

18.NGUYEN, LH., LIU, PH., ZHENG, X., et al., JNCI Cancer Spectr., 2018, 2:pky073.

19.KARAHALIOS, A., ENGLISH, D.R., SIMPSON, J.A., Am J Epidemiol,181,2018, 832

20.LAUBY-SECRETAN, B., SCOCCIANTI, C., LOOMIS, D., et al., N Engl J Med, 375,2016, p.794.

21.NUNEZ, C., NAIR-SHALLIKER, V., EGGER, S., et al., BMC Public Health,18, 2018, p.325.

22.BOTTERI, E., IODICE, S., RAIMONDI, S., et al., Gastroenterology, 134,2008, p.388.

23.MAZILU, L., SUCEVEANU, AI., PAREPA, I.R., TOFOLEAN, D.E., Journal of Carcinogenesis \& Mutagenesis ISSN 2157-25182014, p. 13.

24.DESAUTELS, D., CZAYKOWSKI, P., NUGENT, Z., et al., Cancer, 122,2016, p.1254.

25.SUCEVEANU, A.I., STOIAN, A.P., PAREPA, I.R., VOINEA, C., HAINAROSIE, R., MANUC, D., NITIPIR, C., MAZILU, L., SUCEVEANU, A.P., Rev. Chim. (Bucharest), 69 no. 8, 2018, p. 2260-2267.

26.SHAJI, S., HERNANDEZ, V., PÄR, M., REVITAL, K., EPAMEINONDAS, T., MURAT, T., MARTI-GALLOSTRA, M.,Journal of Crohn's and Colitis, 8 no. 1, 2014, p. 5-18.

27.NITIPIR, C.,BARBU, M.A., ORLOV, C., et al., Romanian biotechnological letters, 24 no. 1, 2019, p.140-146. 
28.STOIAN, A.P., MitrofAn, G., COlCEAG, F., SUCEVEANU, AI., HAINAROSIE, R., PITURU, S., DIACONU, C., TIMOFTE, D., SERAFINCEANU, C., Rev. Chim. (Bucharest), 69 no.9 , 2018, p. 2515-2519.

29.INOUE, M., IWASAKI, M., OTANI, T., et al., Arch. Intern. Med., 166,2006,p.1871

30.COZARU, G., SUCEVEANU, A.I., VOINEA, F., ARS Medica Tomitana, 3 no. 50, 2007, p. 47-53.

31.YAMADA, A., KOMAKI, Y., KOMAKI F., et al., Lancet, 19,2008, p.758

32.TOFOLEAN, DE., MAZILU, L., STANICEANU, F., MOCANU, L., SUCEVEANU, A.I., BAZ, R., PAREPA, R.I., SUCEVEANU, A.P., BONDARI, S., BONDARI, D., VOINEA, F., Romanian Journal of Morphology and Embriology, 56 no. 3, 2015, p. $1205-1210$.

33.OH, M., MCBRIDE, A., YUN, S., et al., J Natl Cancer Inst,110, 2018, p.1178

34.SUCEVEANU, A.I., MAZILU, L., SUCEVEANU, A.P., Colorectal Cancer - Surgery, Diagnostics and Treatment ISBN 978-953-51-1231-0, 2014, p. 403-433.

Manuscript received: 4.09.2019 